\title{
Ethnic Identities And Conflict: Ethnic Conflict Prevention Approach Of European Union
}

\author{
Dr. H. Esra Arcan \\ Communication Faculty, Istanbul University, Turkey \\ earcan2000@yahoo.com
}

\section{Doi:10.5901/jesr.2014.v4n1p27}

\begin{abstract}
Conflicts between ethnic groups are one of the most destructive and devastating forms of conflicts. In the beginning of the Third millennium the world and humankind are still suffering due to conflicts between ethnic groups. Sudan, Rwanda, Yugoslavia, UK-Northern Ireland, Spain, Sri Lanka, and Turkey are some of current examples of these conflicts that caused mass human rights violation and loss of human lives and strained economy and damaged the environment. Therefore preventing conflicts is an important issue that must be addressed and studied. This paper aims to examine, first, ethnicity, ethnicity making situations, causes and forms of ethnic conflicts. Second, it explores what are the main features of ethnic conflict prevention, what is the conflict prevention approach of EU and how EU functions in conflicts. Finally the study concludes that establishing a minority rights protection system is the most effective and humanitarian way to prevent ethnic conflicts.
\end{abstract}

Keywords: Ethnicity, ethnic conflict, ethnic conflict prevention, EU

\section{Introduction: Conceptual and Theoretical Approaches to Ethnicity}

In the beginning of the 21st century, it appears that a much-desired peaceful future is being overshadowed by armed conflicts. All around the world, violent conflicts create tragic stories of human death and destruction. In addition, it causes political instability, unsafe environments, poverty, and interruption of education and healthcare services. Most of these conflicts are described as ethnic in nature and are explained within both cultural and ethnic contexts.

Today, words like 'ethnic,' 'ethnicity' and 'ethnic identity' are used commonly in our daily language. Also the terms 'ethnic kitchen;' and 'ethnic fashion' 'ethnic decoration' are a part of our daily vocabulary. However, these words, and their theoretical concepts, are quite contemporary. Nathan Glazer and Daniel Moynihan (1975: 1) assert that "ethnicity seems to be a new term and the word's earliest dictionary appearance is in the Oxford English Dictionary in 1972. Its first usage is attributed to the American sociologist David Riesman in 1953."Additionally, Raymond Williams (1976: 119) explained that the origin of the word comes from the Greek 'ethnos' and meant "heathen or pagan."

Because of ethnic study's short history and complexity, several scholars such as Eriksen (1993: 4), Royce (1982) and De $\operatorname{Vos}(1995: 18)$ all agree that definitions of ethnicity, ethnic identity and ethnic groups are problematic. In his definition of ethnicity, Eriksen(1993: 6, 12) says:

\begin{abstract}
"Ethnicity is an aspect of social relationship between agents who consider themselves distinctive from members of other groups with whom they have a minimum or regular interaction. It can thus also be defined social identity (based on a contrast vis a-vis others) characterized by metaphoric or fictive kinship... Ethnicity refers both to aspects of gain and loss in interaction, and to aspects of meaning in the creation of identity. In this way it has a political, organizational aspect as well as symbolic one. Ethnic groups tend to have myths of common origin and they nearly always have ideologies encouraging endogamy."
\end{abstract}

As seen in Eriksen's definition, ethnicity is a social or group identity based on contrast to others. With this assertion, some questions emerge: "Who are we?"; "Who are others?"; "How do we identify ourselves?"; "What determinants differentiate our ethnic identities than others?" Essentialist, Primordialist, Instrumentalist and Constructivist approaches give different answers to these questions. In doing so, every theoretical approach also explains the relations between various ethnic groups and the emergence and prevention of conflicts.

Essentialists argued that ethnicity is a given which is deeply embedded and tied to the culture of the ethnic group. Since ethnicity grows organically, it does not change and it is essential for the existence of any ethnic group. Some scholars, by using sociobiological data, such as Van den Berge (1978), even claimed that ethnic nature of human being 
is based on genes ${ }^{1}$. James Kellas (1991) went further and claimed that sociobiological theory can explain ethnic social bonding, and if it is correct, can provide necessary or sufficient conditions for xenophobia, nepotism, slavery, and genocide. But these kinds of essentialist interpretations are criticized and even condemned for legitimizing racism, discrimination and hatred. For instance, Eriksen $(2001: 45,46)$ is one of those scholars who are very critical on essentialism. With the following statement, he takes his position against essentialist interpretation of ethnicity like many others:

"Reification and essentialism have become central terms of denunciation; multiple voices, situational identification, and cultural flows are some of the key words of intellectual agenda. Instrumentalist usage of statements about nations, ethnic groups or cultures that may be picked up or assimilated more or less sub consciously, by ideologists and politicians wishing to build their reputation on national chauvinism, ethnic antagonism, an enemy images, made academia more sensitive about primordialism and essentialism. Thus, it is notonly intellectually correct but also politically correct to reject all forms of essentialism"

As it is pointed out by Eriksen in the above quotation, primordialists share some similarities with essentialists. According to primordialist school, ethnic identities are historically rooted and deeply embedded in a people's culture and collective experiences; therefore ethnic membership does not change. Since ethnic identities are originated from historical circumstances, it creates a belonging, a special group bond and solidarity for the members toward their own ethnic group. Thus, ethnic identities do not shift, are not negotiable and therefore cannot be manipulated. One of the pioneers of this school of thought is Clifford Greeze. In his studies on nationhood in the Third World (1973), he argued that cultural systems are not subject to conscious manipulation of individuals. Related to our subject, this approach can be interpreted as conflicts between ethnic groups becoming unavoidable due to essential and primordial nature of ethnic identities which eliminates the possibility for prevention of ethnic conflicts.

In contrary to primordialist approach, instrumentalist approach showed that ethnic identities are fluid, situational and negotiable thus it can be consciously manipulated by ethnic elites which may be one of the causes for conflicts. In this field, Abner Cohen's works on urban ethnicity in Africa, $(1969 ; 1974)$ and Paul Brass' study on ethnicity and nationalism, (1991) both emphasized the data showing ethnic identity as being fluid and can be altered according to circumstances. Since ethnic identities could shift, it would be open to a conscious manipulation of the elites in an economic competition.

The manipulative capacity of elites on masses can be clearly seen in the rise of Milosevic of Serbia. After the fall of the Berlin Wall, while in some Eastern European countries such as Hungary, Poland, and Czechoslovakia, social and intellectual elites emerged representing ideas and values such as the rule of law, democracy and human rights, Serbia responded to these challenges by returning to the ethnic root and myths of Serbians. "The resistance which arouse towards the creation of a unitary and ethnocentric state Greater Serbia- was characterized by Milosevic and his supporters as an attempt to 'unravel Yugoslavia' and as a 'conspiracy against Serbia and Serbian people" (Briza: 8). Hostile propaganda machinery towards others started first as a war of words then resulted in a devastating brutal war. Milosevic is one of the examples that show the destructive role of elites on mass in conflictual situations. Other example can be seen in the words of Jean-Francois Bayart (2005:88) who summarizes the role and responsibility of elites on masses in Sri Lanka or Rwanda conflicts as follows

"Instead of expressing the spirit of 'peoples' hidden in the depths of their'popular culture' (as the culturalist fable would have it), identity-relatedstrategies betray the hunger of the new elites, eager to be integrated, for powerand wealth. The responsibility of the middle classes, bureaucrats, intellectuals, and students (or dropouts) in the radicalization of identityrelated conflicts-forexample in Sri Lanka, Natal or Rwanda-is often more crushing than that of masses."

As it is argued by the instrumentalist approach, the question of whether ethnic or national communities are created consciously or grow organically was also argued by the constructivist approach. Contributions of Ernest Gellner (1983), Eric Hobsbawm (1983), and Benedict Anderson (1991) have created a turning point in their field with their works. Hobsbawm (with Terence Ranger) and Andersen manifest their approach, even in the significant titles of their books; 'The Invention of Tradition' and 'Imagined Communities'. They argued that traditions and rituals of nations are not old and historical, but are new and invented in order to create cohesion and homogenization in a multiethnic state.

Hobsbawm and Ranger (1983: 1) defined invention of tradition as "a set of practices, normally governed by overtly or tacitly accepted rules and of a ritual or symbolic nature, which seek to inculcate certain values and norms of behaviour

${ }^{1}$ Van der Berg was inspired by the study of Davkins, Richard (1976) Selfish Gene, Oxford University Press. 
by repetition, which automatically implies continuity with the past' They showed how rituals and symbolic representations operate through social process and cultural media and create ethnic/national and imagined/invented boundaries. Without the industrial economy, modernization, and central state structure, there would be no ethnicity or nation.

An example of constructed ethnic identity and instrumentalization of it can be found in the story of people of Rwanda where one of the bloodiest ethnic conflicts and genocide occurred. In the very plain narrative of Percival and Dixon (1996: 272-273), they expose the construction of an ethnicity, and ethnic identity that objectively never existed. Connection to colonialism, and the role of power relations, and interests of dominant power in the construction process are also explicit in their study.

\begin{abstract}
"Rwanda's history shows that the terms Hutu and Tutsi were largely constructed social categories representing differing socio economic positions within Rwandan society rather than objective biological or cultural differences. The Hutu-Tutsi distinction derives from a pre-colonial social structure that distinguished between cultivators and pastoralists. Before the growth of central power and colonial domination, the boundaries between the Hutu and Tutsi were fluid...Perhaps the greatest determinant of ethnicity was the possession of cattle; those who possessed cattle were Tutsi, and those who did not were Hutu.

With the growth of pre-colonial state power, Tutsi and Hutu became important political categories. With the establishment of colonialism, the boundaries of ethnic categories were thickened; it became increasingly difficult to alter one's social status or ethnic grouping. The disadvantages of being Hutu and the advantages of being Tutsi were sharpened under first German and then Belgian colonial rule."
\end{abstract}

In conclusion, ethnicity and ethnic identity are explained by different theoretical framework of Essentialism, Primordialism, Instrumentalism, and Constructivism. Since numerous studies obtained quiet convincing data against essentialist and primordialist thesis today, it seems scholars are more cautious than ever on essentialism and primordialism, as it is echoed in Eriksen's words in the previous page.

\title{
2. Ethnicity Making Situations: Ethnic Typology and Its Relation with Minorities
}

Because of immigration, colonialism, slavery, etc. which is aptly named ethnicity making situations by Eriksen (1993: 13); there is almost no ethnically pure and homogeneous society in our modern world. States are multi ethnic and societies are multicultural. Presence of about 6000 languages and about 1600 major cultural groupings indicate a worldwide ethnic diversity (Robin, 1993: 49).

Eriksen(1993: 13-14) identifies four ethnic typologies as urban ethnic minorities, indigenous peoples, protonations, and ethnic groups in 'plural societies'. Steve Fenton (1999: 32-33) adds a fifth typology as post-slavery minorities for a classification of "ethnicity-making situations".

1. Urban ethnic minorities; include immigrants, migrant workers in industrial urban areas, such as Mexicans in US, Indians in UK, Turks in Germany who migrate to these countries for economic purposes.

2. Indigenous peoples; includes native inhabitants of a territory, such as Native Americans in American continent, Aboriginal Peoples of Australia and New Zealand. Indigenous minorities are usually in non-industrial mode in production and partly integrated into the dominant nation state system.

3. Ethnic minorities in plural (multiethnic) societies; most contemporary states are multiethnic, ethnically and culturally heterogeneous societies, either because of old migration waves, or natural multiethnic population of the state such as; US, UK, France, Spain, Turkey, Kenya, Indonesia.

4. Proto-nations or ethno-national groups; minority groups in plural societies who claim to be nations, and thus make a claim for a form of self-governance within a wider state or to secede from a state. Irish, Welsh in UK, Basques in Spain, Kurds in Turkey, and Quebecois in Canada are some of the most known proto-nations. Since some of them had/have armed struggle organizations and armed conflicts with the states (IRA against UK, ETA against Spain, PKK against Turkey), they are also called ethno nationalist movements.

5. Post-slavery minorities; includes people who were forcibly brought to a country as slaves, the descendants of formerly enslaved African people in the New World.

As it can be seen above, Eriksen and Fenton both named and identified three of the ethnic groups as minorities, because ethnicity making situations are also minority making situations. If ethnic groups are not dominant or equal in the power sharing mechanism, these ethnic groups are then called minorities. The criteria for ethnic identification of minorities are several. Minorities may identify their distinctiveness from others based on;

a) Race; such as African Americans,

b) Kinship; like in some African tribes, 
c) Religion; for instance Bosnians in former Yugoslavia,

d) Language, such as Quebecois in Canada,

e) Customary mode of livelihood; such as the Roma,

f) Regionalism; possible example may be Eastern and Western Germans.

There is no universally accepted definition of the minority concept, yet. Minority Rights Group International's definition that is used in its studies is one of the most comprehensive definitions to date. It defines minority as; " $A$ group of people, usually a numerical minority (although sometimes a majority) who are different from the dominant group(s) in ethnic origin, language, religion, culture, and status, and who suffer prejudice, discrimination or exclusion".

The words prejudice, discrimination, and exclusion in the definition underscore vulnerable situations for minority groups and imply a potential of conflict. Minority ethnic groups suffer at many levels; multi ethnic societies have a visible or invisible ethnic hierarchy. If the country is not autocratic, or theocratic, on surface; every citizen of the country appears to be equal and to have equal rights. But in reality most of minority ethnic groups are in the bottom of the economic and social strata. They are usually the poorest and the most marginalized groups not only in the Third World countries but also in the most developed Western Countries. This is why ethnicity and conflict comes together in the concept of ethnic conflict. Unless, they are protected by proper human and minority rights systems as equal citizens of the state, potential for conflict becomes high.

\section{Discussions Regarding the Term of Ethnic Conflict}

Conflict is defined, variously, as a struggle or clash of ideas, principles, people, or peoples. Ethnic conflict is one form of conflict which is defined by Wolff (2004: 1 ) as follow

"...the goals of at least one conflict party are defined in (exclusively) ethnic terms, and in which the primary fault-line of confrontation is one of ethnic distinctions. Whatever the concrete issues over which conflict erupts (e.g., linguistic, religious, or cultural rights and/or corresponding claims to conditions conducive to their realisation), at least one of the conflict parties will explain its dissatisfaction in ethnic terms, i.e., will claim that its distinct ethnic identity, and lack of recognition thereof and/or equality of opportunity to preserve, express, and develop it, is the reason why its members cannot realise their interests, why they do not have the same rights, or why their claims are not satisfied."

Following the Wolf's definition, we can distinguish some peculiarities of ethnic conflicts. First of all, they are based on some concrete issues such as linguistic, religious, or cultural rights that are important to the survival of ethnic groups' distinctive character. Secondly, conflicts are based on lack of recognition, and unsatisfied claims as addressed in the definition. Therefore, Wolf (2004: 1) concludes that ethnic conflicts are over unsatisfied demands of minorities. It is partly true but Wolf (2006: 2) whit his statement of "Empirically, it is easy to determine which conflict is an ethnic one: one knows them when one sees them" tends to oversimplify the complexities of ethnic conflicts.

On the other hand, several scholars disagree on framing conflicts on ethnic demands or minority issues alone. One of the opponents is Phillips and he, without any hesitation says "ethnic conflict is a misnomer...it is simplistic and dangerous to give too much currency to the phrase 'ethnic conflict"'. By saying this, he (1995: 5-6) opposes not only the term but also the definition of ethnic conflict that is framed on ethnic issues or minority rights alone. He quotes from the discussions of the NGO World Congress on Human Rights, New Delhi, 1991, and draws attentions to the unveiled content of ethnic conflicts as follows;

"The phrase 'ethnic, social, and religious conflict' is often a misnomer and leads to false perception. Such conflicts are frequently incited by certain politicians (and certain religious leaders) manipulating the situation to obtain power and to control resources. Tensions between communities largely emanate on the question of control of resources and are heightened by depressed economic dislocations."

In addition of ethnic issues and minority rights, ethnic conflicts are also over obtaining economical gain and power as it was explained by instrumentalist and constructivist theories. NGO World Congress on Human Rights reiterated this as seen above.

Another opponent Eriksen (2001) also says that the concept of ethnic conflict is misleading and shows with several examples in which conflicts are over resources that are perceived to be scarce: territory, political power, economic gain,

${ }^{2}$ G. Alfredson and E.Ferrer as updated and revised by K. Ramsey. (2004) Minority Rights: A Guide to United Nations Procedures and Institutions. London: MRG. Footnote: 3 
employment, recognition. Instead of ethnic conflict, he suggests the term of "identity politics" as preferable generic term for all such political movements, whether violent or non-violent. Identity politics refer to a movement that is built on collective identities such as ethnic, religious or gender. But it should be emphasized that, conflicts between groups are not because of their different ethnic origins, cultural believes or religious doctrines, but because of their different interests. Schirmer (1998: 117) also agrees with that and he draws attention to the reality of "cultural conflicts are not only about attitudes and prejudices but are also about power and the distribution of opportunity".

As a term, ethnic conflict is a conflictual in itself. In one hand, from media news to scientific studies, it is used widely and has permeated our daily language; on the other hand there is a rising objection to the term itself, its content and the study field of it. ${ }^{3}$ These arguments are all important and valid since terms, their content and definition all determine the characteristics of the concept at a theoretical level.

In light of all these discussions, the term "ethnic conflict" which is in the title of this study, should be used very carefully. From now on, ethnic group conflict or conflict between ethnic groups will be used interchangeably instead of the term ethnic conflict to avoid legitimizing and perpetuating misperceived connections among ethnicity, ethnic identity and conflict.

\section{Causes and Forms of Conflict between Ethnic Groups}

\subsection{Causes of Conflicts between Ethnic Groups}

In 2005, in 22 countries, 31 armed conflicts were recorded. During 1990s, 37 countries had 50 conflicts as yearly average. (PRIO Press Release, 2006) What dynamics and causes create conflicts between ethnic groups? As we see in the previous part, ethnic issues, minority rights, and power and source distribution were mentioned as distinguished peculiarities of conflicts between ethnic groups. In this part we will try to examine the main dynamics that causes and forms these conflicts between ethnic groups. These questions are addressed in different ways by different theoretical schools. Some of the major theories are: security dilemma theory, ethnic nepotism theory, social identity theory, development theory, and social transition theory. (Zartman, 1998)

"Ethnic nepotism theory refers to the situation of groups hiring their own kind to promote survival, and this then leads to distributive conflicts". (ibid)This theory emphasizes the dominant status quo of an ethnic group and unequal distribution they created as the cause of conflicts. "Social identity theory suggests that unequal distribution of resources produces conflict when the subordinate group rejects its previously accepted negative self-image and with it the status quo, and starts working toward the development of a positive group identity. When social identity based on intergroup comparisons is unsatisfactory, individuals will either strive to leave the group for a better identity or make their own group more positively distinct, thus causing conflict." (ibid) In its suggestion, social identity theory also emphasizes dominant and subordinate status quo of ethnic groups and unequal distribution of resources. "Development theory addresses this problem by indicating that an established pecking order among identitygroups will be called into question when exogenous changes provide new opportunities for achievemental mobility that the old order did not allow. Dominant groups then see their positions threatened by newly liberated groups." (Zartman, ibid) By referring to opportunities of achievemental mobility this theory also considers raising status quo of the subordinate ethnic groups in power relations and in redistribution.

As seen above, most of the theories explain conflicts based on power relations and status quo of ethnic groups as they relate to the distribution of resources. Power relations between ethnic groups and dominant or subordinate status quo of the ethnic groups are the most stressed factors in these theories because they determine the share of ethnic groups in distribution of resources. Ethnic groups who have dominant status quo in power relations take the lion share of the resources. Therefore we can conclude that two main dynamics that cause conflicts between ethnic groups are the power struggle and the distribution of resources which are compatible with the findings of the previous part.

\subsection{Types of Conflicts between Ethnic Groups}

Types and forms of conflicts between ethnic groups are other significant subjects. Positions and risks of minority groups in conflicts can be analyzed by identifying the form of conflicts. In doing so, we will also explore who are in a conflict and

${ }^{3}$ Bruce Gilley totally rejects the study field of ethnic conflict for misdirecting the political realities in his article that is titled "Against the Concept of Ethnic Conflict". Third World Quarterly, (2004) Vol. 25, No. 6, pp.1155-1166 
what is the nature of their relationships. Eide, (1993: 11) identifies four forms of conflicts which could be grouped as follows;

a) Dominant center v. peripheral group,

b) Dominant or host society v. discriminated group

c) Communal contenders v. communal contenders

d) Ethnonationalist v. secessionist/ethnonationalist.

In all four conflict situations, it seems the main problem arises between the dominant and subordinate group relations. Therefore, it can be said that group conflicts are the results of social, economic, cultural domination in the context of power relations. As it is mentionedearlier, in the definition of minority, subordination and domination in group relations is one of the determinants of a minority position.

Accordingly Eide's conflict type's categorization, we can understand the position of minority groups in conflictual situations.

a) Dominant center vs. peripheral group: explains a conflict in terms of the tension between periphery and center, one example could be the indigenous peoples' position. Eide states that "groups whose traditional way of life and resources base are challenged by a dominant centre that exploits the resource base of the group and in the process also destroys the capacity of the peripheral group to reproduce and to develop its own culture, including language and religion" (Eide, ibid). Rotchild (1981:72) defines the same situation as "a dominant central core or plurality versus of peripheral ethnic segments" and points out that "here the core group views itself as the historic, institutional, and symbolic creator, and hence appropriate hegemon of the state." One of his examples is the situation in Iran; Persians of the central plateau, as hegemon Vis a Vis the peripheral to Arabs, Kurds, Azeri, Turkmens and other minority groups.

b) Dominant or host society vs. discriminated group: explains the cases in the term of tension between discriminated group and dominant or host society. Position of Black African minority in US, Brazil or South Africa is one example. Eide, (ibid: 10) suggests that "the efforts of groups that are discriminated against to obtain equality. Most obvious are the efforts by group discriminated against because of their colour or race, but many recent immigrants also experience discrimination on the basis of their ethnic or religious origin. Their identification as a group arises largely out of the negative attitudes held towards them by the dominant or host society. The primary struggle is for the equal enjoyment of civil, economic and social rights...citizenship and full political rights."

c) Communal contenders vs. communal contenders: explains the situation in the term of tension between communal contenders, ${ }^{4}$ who claim share in power without dominating of or seceding from national society. According to Eide(ibid: 11$)$ post-colonial societies are the examples since "in most post-colonial societies where borders weredrawn rather arbitrarily by colonial powers in such a way that different ethnic groups, tribes or culturally distinct clans come to be included within the same state. Such cases are primarily a struggle for political power, and for the benefits deriving from the holding of power-not only for the power-holders themselves, but also those other members of the tribes or ethnic groups who are rewarded through a clientelist relationship for having supported the people in power."

d) Ethnonationalists vs. secessionist/ethnonationalists: explains the conflict in term of tension between ethnonationalists and secessionists. Again, if we follow the definition of Eide (ibid: 11), "Ethnonationalists are people, using a relatively large and geographically concentrated ethnic group as a basis, who seek either to dominate a heterogeneous national society or to secede from it". The situation includes two different types of ethnonationalists. First is a dominant ethnonationalism that is usually coupled with a state power and represents a state. The second one is not dominant and usually represents a minority group that is oppressed by the state. Dominant ethnic groups' policy consists of assimilation, exclusion and discrimination strategies against the subordinate ethnic groups. The alternative strategy for a second type secessionist ethnonationalism is "establishing an independent state which their ethnic group can dominate or redraw borders to become part of another state dominated by their own ethnic group" (Eide, ibid: 11). Conflict between an ethnonationalist state and ethnonationalist movement results in violent conflict. During this violent conflict, existing cultural, social, political, economic discrimination and oppression is exacerbated, as it results in a vicious cycle.

${ }^{4}$ The notion of communal contenders that has been used by Ted Gurr and means culturally distinct groups in heterogeneous societies who hold or seek a share in a state power. See Gurr, Ted. (1993) Minorities at Risk A Global View of EthnopoliticalConflict. Washington DC: United States Institute of Peace. p. 18 
As seen above, almost every conflict theory and conceptual discussion agrees that discriminatory policies of the dominant power and unequal status of a group, along with unequal distribution of resources are the reasons of conflicts between groups. Additionally, forms of conflict situations are the result of hegemonic, dominant relationships between ethnic groups.

\title{
5. Definition of Conflict Prevention
}

The idea of conflict prevention is not new idea. It has been discussed since the $18^{\text {th }}$ century. Essentially EU is a result of a conflict prevention attempt of Europe following the devastating Second World War. As it is stated in the UN Charter Article 1, Security Council is also charged with taking "effective collective measures for the prevention and removal of threats to the peace" which means the League of Nations and the United Nations were all established with the explicit intent to prevent conflict. Therefore, one can say that the concept andattempts of conflict prevention are not new. Nevertheless, it became more emphasized when the former UN Secretary General Boutros Boutros-Gali released the report, An Agenda for Peace in response to the Security Council's request for recommendations to improve the UN's capacity for preventive diplomacy, peacemaking, and peacekeeping.

Although a certain consensus of desirability of conflict prevention can be identified, there is still no consensus on the term and its meaning. A compact definition of conflict prevention that is made by Emma Stewart (2003) can give us an idea what conflict prevention is:

\begin{abstract}
"In general terms, conflict prevention in the international arena refers to any attempt by third parties to prevent the outbreak of violent conflict. Conflict prevention is a multifaceted, complex process ranging from long-term or structural policy to promote stability, to short-term intensive diplomacy to resolve disputes ("preventive diplomacy") and civilian or military intervention to monitor and/or control the early stages of conflict ("crisis management"). It also refers to attempts to stop the recurrence of violence in conflict zones ("peace-building" or "post-conflict reconstruction/rehabilitation"). It is therefore an activity primarily, although not exclusively, concerned with the period before the outbreak of war."
\end{abstract}

Prevention attracts a lot more interest since the material costs and the amount of suffering is significantly less in a conflict subdued at an early stage than a conflict that is fully developed. Prevention becomes more attractive when we consider the immense cost of post-conflict reconstruction (Hettne and Soderbaum, 2005). Even if the international organizations and their diplomatic strategies can create vague definitions of conflict prevention, and some scholars in the field are skeptic about it, the former Secretary General of UN, Kofi Annan (1999) made the most convincing defense of conflict prevention. During the presentation of CornegieCommission on Preventing Deadly Conflict Report, he said "For the United Nations, there are no higher goal, no deeper commitment and no greater ambition than preventing armed conflict. The preventing of conflict begins and ends with the protection of human life and the promotion of human development. Ensuring human security is in the broadest sense, the United Nations' cardinal mission. Genuine and lasting prevention is the means to achieve that mission". Conflict prevention includes short and long term solutions; complex and multidimensional efforts to prevent non-violent or violent conflicts from escalating into war and preventing earlier wars from erupting again. Mainly, conflict prevention has two fundamental strategies: operational prevention and structural prevention (Annan, ibid).

\subsection{Operational Prevention}

Operational prevention functions as a short and medium term strategy and includes four fundamental activities:

a) Early warning: includes identifying rising tension and emerging conflicts; collecting Information by fact finding and other data gathering methods that are then translated in to early warning signals so that international and regional organizations can be warned.

b) Preventive diplomacy. non-coercive, low-key and confidential diplomacy in its approach that is not restricted to officials. Private individuals as well as national and international civil society organizations can play active roles therefore also known as "citizen diplomacy". Forms of preventive diplomacy could be mediation, conciliation, or negotiation. Some successful implementations of preventive diplomacy have been exercised by 'good offices' of UN.

c) Preventive deployment: that is intended to provide a 'thin blue line' to help contain conflicts by building 
confidence in areas of tension or between highly polarized communities. ${ }^{5}$

d) Early humanitarian action: focuses on humanitarian needs of civilians in early stage of conflicts, in a way emergency assistant such as, obtaining food, water, medicine, medical care, shelter.

\subsection{Structural Prevention}

Structural prevention functions as a medium and long term strategy that includes three additional activities:

a) Preventive disarmament: seeks to reduce the number of small arms and light weapons in conflict-prone regions. Preventive disarmament efforts are also increasingly directed towards slowing small arms and light weapons trafficking, the only weapons used in most of today's armed conflicts.

b) Development: Armed conflicts destroy a country's physical infrastructure, divert scarce resources, and disrupt economic life, including food supplies. Therefore, economic development and developing other sources of income are important long term aims of conflict prevention by development policy that restructures society economically, socially and politically.

c) Peace Building: In long term, planned measures to handle the core causes of conflicts involve activities such as good governance, democratization, integration of ethnic groups and minorities, constructing dialog between communal groups, restructuring the police and military forces, strengthening and mainstreaming human rights, and creating and institutionalizing prevention culture. ${ }^{6}$

\section{Conflict Prevention Approach of the EU}

In Europe, conflict prevention has become the centre stage in foreign policy debates. "Nowhere else is conflict prevention explored with such seriousness of purpose, and nowhere else has it been institutionalized as deeply" says Menkhaus (2004) and praises EU for its serious conflict prevention efforts. One of the proofs of serious effort of the EU is its close collaboration with The Organization for Security and Cooperation in Europe (OSCE) that isfounded on the goal of preventing conflicts in Europe. Additionally, the Council of Europe's (CoE) role in standard setting to protect human rights and minority rights is remarkable. One of the main achievements of $\mathrm{CoE}$ in this regard is the European Convention on Human Rights as a general framework of protecting human rights of minorities in conflicts.

As part of their military and diplomatic efforts, it is well known that several European states have trained and financially supported peacekeeping forces for the UN's preventative deployment activities. Several EU member countries have played leading mediating roles in preventative diplomacy. But more than military conflict prevention, EU's approach may be considered non-military.

Additionally the EU has put a remarkable effort to conceptualize a more sophisticated approach to conflict prevention. The first important contribution was the discussions on using EU aid budget to prevent and end conflicts that appeared in the European Commissions' policy paper on Linking Relief, Rehabilitation and Development (1996). Second development was to abandon the traditional concept of conflict and acknowledge the importance of the structural causes of violent conflicts which appeared in the European Commissions' policy paper The European Union and the Issue of Conflicts in Africa: Peace-building, conflict prevention and beyond (1996). Despite the progresses at the conceptualization level, the EU had and still has problems at the policy implementation level. However, one of the

${ }^{5}$ Feil, Scott R. (in"Could 5,000 Peacekeepers Have Saved 500,000 Rwandans? Early InterventionReconsidered," ISD Reports III, No. 2, Institute for the Study of Diplomacy, Georgetown University, Washington, DC, April 1997.) explains with details a very tragic missed opportunity of preventive deployment is experienced in Rwanda, despite of enough early warnings not taking action of preventive deployment cost hundreds of thousand lives. The commander of the United Nations Assistance Mission for Rwanda (UNAMIR), Major General Romeo Dallaire of Canada, maintained that a capable force inserted within two weeks after the death of the presidents could have stopped much of the killing and removed the pretext for the continuation of the civil war. In his assessment, 5,000 troops operating under a peace enforcement mission (Chapter VII of the UN Charter) with air force, communications, and logistics support, could have: prevented massive violence; assisted in the return of refugees and displaced persons; protected the flow of humanitarian aid; and provided a secure environment to enable talks between Hutus and Tutsis to devise mechanisms to ease tensions between the ethnic groups.

${ }^{6}$ For details about conflict prevention methods, stages and prevention culture: Annan, Kofi. Towards a Culture of Prevention: Statements by the Secretary-General of the United Nations. Cornegie Commission on Preventing Deadly Conflict. New York: Cornegie Corporation.; Theory Development in Conflict Prevention and Conflict Management Workshop Proceedings. Published by Central Asia-Caucasus Institute and the Silk Road Studies Program, Uppsala 2005; Lund, M. 1996. Preventing Violent Conflict: A Strategy for Preventive Diplomacy. Washington DC: US Institute of Peace 
achievements of the EU by using aid for conflict prevention is the case of Liberia and is worth mentioning. Since 1996 aid funds have been used directly by the European Commission Liberia Desk to restore peace, and to secure democracy. Liberia is especially an important case for our subject, since the main reason of group conflict in Liberia was explained by cultural or ethnic differences in values (UN Human Development Report 2004: 40). Samuel Huntington's (1993: 41) well known prediction of "clash of civilization" was the main reference for this type of interpretation. Success in Liberia in preventing conflict and building a more peaceful atmosphere shows that cultural differences are not the primary cause of the conflict and points out to the serious flaws in the primordialist and essentialist approaches that are "based on incorrect view of the formation, role and malleability of identities" (UN ibid: 41). Now it is accepted that conflict between ethnic groups in Liberia was due to control of natural resources (ibid: 41).

Aid programming to prevent conflicts, have been implemented through different process and institutions that are based on the Treaty of Rome since the European Community (EC) era. The European Commission (ECom) as the Executive Body of EC stands as the main body for aid programming and engages in conflict prevention through aid programs and policies such as Lome IV, PHARE/TACIS, Euro-Med Partnership or with its new title EU Neighbourhood Policy in which developing human rights, gender and democratization in the EU and other societies are some of the main focus points.

Besides using aid programs, the second important pillar of EU's conflict prevention is the Common Foreign and Security Policy (CFSP) that was established in 1992. In spite of its certain function and utility, there are some difficulties in practice. As it is stressed by Costy and Gilbert (1998) "CFSP reflects an intergovernmental compromise between, on one hand, the perceived need to build a common foreign policy and, on the other, Member states' lingering fears about surrendering national sovereignty". Recently the EU has been under pressure by its members to restructure a new and more effective conflict prevention mechanism. As it could cause conflict with some members' external policies, it is not easy to implement working with 27 national capitals and a number of supranational institutions. The structure of the EU Foreign and Security Policy is based on decentralized decision making. Since there is no centralized policy and different institutions and programs are involved in the decision making process, difficulties occur in CFSP's international activities.

Commitment to conflict prevention of the EU was clearly declared in the statement of the government policy in the parliamentary debate on foreign affairs in February 2001. During the EU presidency of Sweden, it was stated that the EU will work to prevent conflict based on the following premises:

"The EU has immense potential in conflict prevention. We want to strengthen this capability. Given its scope and its history as a peace project, the EU can play a vital role in preventing violent conflicts, in the global arena also. We will therefore seek to ensure that the European Council in Goteborg adopts a programme of tangible proposals on ways in which the EU can be more effective at conflict prevention. Few conflict management operations are exclusively military. We have accordingly developed an integrated approach to conflict prevention and civil and military crisis management. It is alsoimportant that these efforts be coordinated with development assistance at all stages of the process."

In order to prevent such conflicts in Europe other than EU, another European organization, Organization for Security and Co-operation in Europe (OSCE, previously Conference for Security and Co-operation in Europe, CSCE) also functions very effectively. OSCE deals with conflict warning, prevention, crisis management, and post conflict rehabilitation tasks. Two main institutions of OSCE contribute effectively to the field. Office for Democratic Institutions and Human Rights promotes human rights and democratization; High Commissioner of National Minorities primarily addresses minority issues before they evolve into serious problems. Co-operation between the EU and OSCE is remarkable. Especially through the EU accession process of Eastern Europe relating to the protection of minority rights.

Since a direct link between protection of minority rights and conflict prevention has been agreed on, Europe, besides conflict prevention, has focused on establishing a minority rights protection system in an enlarged Europe.

\section{Relationship between Minority Rights Protection System and Conflict Prevention}

As shown earlier, causes of conflicts between ethnic groups are mostly related to social, cultural, political and economic discrimination and violation of human and minority rights by the dominant majority groups. Thus, protection of minority rights and providing a socially and economically just society is essential in conflict prevention.

Former General Secretary of UN, Kofi Annan remarked the following statement as he presented the Millennium Report 2000 "the best way to prevent conflict is promote political arrangements in which all groups are fairly represented,

7The statement is available at: $h$ ttp://www.regeringen.se/content/1/c6/01/89/85/9b6d3493.pdf 
combined with human rights, minority rights, and broad-based economic development."8 With this statement, Kofi Annan underscores the importance of a democratic governance that treats the citizens equally which is only possible with a human and minority rights protection system. Governance that isaccountable, transparent, and respectful to the human and minority rights could only be achieved by democratic and pluralist governments. Importance of ensuring human rights and minority rights for preventing conflicts is also underscored by Rolf Ekeus, OSCE High Commissioner on National Minorities by the following statement in which he stresses the pragmatic function of it as well:

\begin{abstract}
"Safeguarding respect for human rights is one of the most fundamental and effective means of preventing conflict. It is not only the right thing to do; it is the wise thing to do. Governments intent on preserving peace, stability and harmonious relationships within the state and with its neighbours, should make every effort to establish a political, institutional and practical framework that ensures respect for the human dignity and rights of all persons."
\end{abstract}

As it is stressed by the High Commissioner, respecting human rights is not only the right thing to do but it is also the wise thing to do. Cost of conflict resolution is always much higher than preventing a conflict before it escalates, not to mention the cost of human tragedy.

Additionally, Amnesty International, Federation Internationale des Ligues des droits de l'Homme, Open Society Institute, World Organization Against Torture, and Coalition for the International Criminal Court recommended to the European Parliament and its four committees and a subcommittee that minority rights and conflict prevention is globally interconnected. Since supporting minority rights and democratization efforts help prevent conflict, budget for these kinds of efforts should not be reduced. Their suggestion to the European Parliament is as follows:

\begin{abstract}
"In particular, we believe paying proper attention to minority rights-broadly defined-would contribute significantly to the prevention and resolution of conflict - as has been understood by the EU in its application of the Copenhagen Criteria. To bring about real change in this field, we feel it is critical that the human rights/minority rights and the conflict resolution agendas are recognized as complementary. In our view, it is important to accept that conflict prevention and minority rights as interconnected globally." 10
\end{abstract}

\title{
8. Conclusion
}

In the beginning of the 21st century, it appears that a much-desired peaceful future is being overshadowed by armed conflicts. All around the world, violent conflicts create tragic stories of human death and destruction. In addition, it causes political instability, unsafe environments, poverty, and interruption of education and healthcare services. As it is emphasized by the authorities of the international, intergovernmental and nongovernmental organizations, protection of minority right is the most effective and humanitarian way to prevent conflicts. By recognizing this reality, EU focused on minority rights as one of the main criteria of enlargement of the EU. According to Copenhagen Criteria, providing minority rights became an imperative for the new EU members in the accession process. Despite some flaws, Western Europe has accommodated one of the most developed and the best minority rights protection systems. By examining the European minority rights protection system, institutions and organizations, we can better understand what role minority rights accommodation can play in a society and as a result how minority rights can be a key to prevent conflicts.

\section{References}

Anderson, Benedict. 1991. Imagined Communities: Reflections on the Origin and Spread of Nationalism, London: Verso Annan, A.Kofi. (1999) "Facing the Humanitarian Challenge: Towards a Culture of Prevention". In Perspectives on Prevention Pamphlet Series, Carnegie Commission on Preventing Deadly Conflict, USA pp. 17-23

Bayart, Jean-Francois. (2005) The Illusion of Cultural Identity. London: Hurst \& Co. (Publishers) Ltd.

Brass, Paul. 1991. Ethnicity and Nationalism: Theory and Comparison. London: Sage Publication

Briza, Jan. Minority Rights in Yugoslavia. London: Minority Rights Group International.

Cohen, Abner (1974) Two-dimensional man: An essay on power and symbolism in complex society. London: Routledge\& Kegan Paul.

Cohen, Abner.(1969) Custom and politics in urban Africa: A study of Hausa migrants in a Yoruba town. London: Routledge\& Kegan Paul;

Costy, A \& S. Gilbert. (1998)Conflict Prevention and the European Union: Mapping the Actors, Instruments, and Institutions. Co-

${ }^{8}$ The statement of Kofi Annan is available at: http://www.unchr.ch/minorities

${ }^{9}$ Addressed by Rolf Ekeus to the Human Dimension Implementation Meeting Warsaw, Poland 2 October 2006

${ }^{10}$ Letter to the EP is available at: http://www.omct.org/pdf/omct_europe/2004/letter_ep_eidhr2005_16_08_04.pdf 
Published by International Alert and FEWER

De Vos, George A. (1995) "Concepts of Ethnic Identity", in Ethnic Identity: Creation, Conflict, and Accommodation (eds: Lola Romanucci-Ross, George De Vos) Third ed. Walnut Creek : Altamira Press

Eide, Asbjorn. (1993) New approaches to minority protection. MRG Report Series. London: Minority Rights Group

Eriksen, Thomas H. (1993) Ethnicity \& Nationalism: Anthropological Perspectives. Boulder: Pluto Press.

Eriksen, Thomas. (2001) "Ethnic Identity National Identity, and Intergroup Conflict" (eds) Ashmore\&Jussim\&

Wilder. In Social identity, Intergroup Conflict, and Conflict Reduction. New York: Oxford University Press. pp. 42-68

Fenton, Steve. (1999) Ethhnicity: Racism, Class and Culture. London: Macmillan.

G. Alfredson and E.Ferrer as updated and revised by K. Ramsey. (2004) Minority Rights: A Guide to United Nations Procedures and Institutions. London: MRG

Geertz, Clifford. (Ed) (1967) Old societies and new states: The quest for modernity in Africa and Asia. New York: The Free Press

Geertz, Clifford. (1973) The interpretation of cultures. New York: Basic Books.

Gellner, Ernest. (1983) Nations and nationalism. Oxford: Blackwell; (1997) Nationalism. London: Wiedenfeld\&Nicolson.

Gilley, Bruce "Against the Concept of Ethnic Conflict". Third World Quarterly, (2004) Vol. 25, No. 6, pp. 1155-1166

Glazer, Nathan and Daniel A Moynihan, (1975) (eds) Ethnicity: Theory and Experience. Cambridge, Mass: Harvard University Press.

Gurr, Ted. (1993) Minorities at Risk A Global View of EthnopoliticalConflict. Washington DC: United States Institute of Peace.

Hettne, Bjorn and FrederikSoderbaum 2005 "Intervening in Complex Humanitarian Emergencies: The Role of Regional Cooperation". The European Journal of Development Research, Vol.17, No.3, pp.449-461

Hobsbawm, Eric \& Ranger, Terence. (1983)(eds), The Invention of Tradition. Cambridge: Cambridge University Press.

Huntington, Samuel. "Clash of Civilizations". Foreign Policy, Summer 1993 Vol.72, No. 3

Kellas, James G. (1991) The Politics of Nationalism and Ethnicity. London: Macmillan.

Menkhaus, Ken. 2004. "Conflict prevention and human security: issues and challenges". Conflict, Security \&Development, 4:3 December. pp. 419-63

Percival, V and T. H Dixon. (1996) "Environmental Scarcity and Violent Conflict: The Case of Rwanda". Journal of Environment \& Development, Vol. 5, No. 3, pp. 270-291

Phillips, Alan. (1995) In introduction of New Approaches to Minority Protection, by AsbornEide. London: Minority Rights Group.

PRIO Press Release (2006) International Peace Research Institute, Oslo (PRIO) Center for the Civil War Press Release, 4 September 2006

Rotschild, Joseph. (1981) Ethnopolitics: A Conceptual Framework. Newyork: Columbia University.

Royce, Anna. P, (1982) Ethnic Identity: Strategies of Diversity, Indiana: Indiana University Press

Schirmer, Dietmer. (1998) "Integration and Fragmention Discourses: Demanding and Supplying "Identity" in

Diverse Societies".inFinzch,N\& D. Schirmer. (Eds.) Identity and Intolarance: Nationalism, Racism, and Xenophobia in Germany and United States. Cambridge: Cambridge University Press.

Stewart, Emma. (2003) Conflict Prevention: Consensus or Confusion available at: http://www.peacestudiesjournal.org.uk/docs Iconflictprevention.pdf

UN Human Development Report, 2004, New York: United Nations Development Programme,

Van den Berghe, Pierre. 'Race and Ethnicity: a sosiobiological perspective', Ethnic and Racial Studies, 1978 Vol. 1: 4

Williams, Jr., Robin M. (1993) "The Sociology of Ethnic Conflicts: Comparative International Perspectives"Annual Review of Sociology, Vol.20.

Williams, Raymond. (1976) Keywords. London: Flamingo

Wolff, Stefan. (2004) Conceptualising Conflict Management and Settlement in (eds) Scheneckener\& Wolff, Managing and Settling Ethnic Conflicts London: Hurst

Wolff, Stefan. (2006) Ethnic Conflict: A global perspective. New York: Oxford University Press,

Zartman, William. "Managing Ethnic Conflict." Foreign Policy Research Institute WireVol. 6, No. 5 September 1998 
